\title{
ИЗУЧЕНИЕ ПСИХИЧЕСКИХ СОСТОЯНИЙ ТЕННИСИСТОВ РАЗНОЙ КВАЛИФИКАЦИИ ВО ВРЕМЯ СОРЕВНОВАНИЙ
}

\author{
Цагельникова А.А., Боярина Ю.С., Цьганов О.В. (Белорусский \\ государственный университет фризической культуры, Минск, Беларусь) \\ sim241980@mail.ru

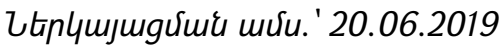

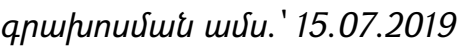

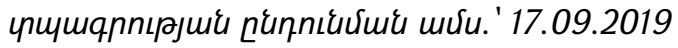 \\ В статье мы изучили психические состояния теннисистов разной
} квалификации в процессе соревновательной деятельности. Представлены результаты психологического тестирования и результаты педагогических наблюдений за внешними признаками соревновательного эмоционального состояния теннисистов до 14 лет разной спортивной квалификации.

Ключевые слова: психические состояния, психологическое тестирование, психологическая готовность, соревнования, эмочиональные проявления.

Игровая деятельность теннисиста протекает на фоне значительных фиизических, психических, умственных и эмоциональных нагрузок, при наличии множества внешних раздражителей и сбивающих фракторов. Ориентирование в пространстве и во времени в процессе спортивного поединка в теннисе усложнено подвижным эмоциональным фоном. При этом следует подчеркнуть многократную контрастность эмоций, связанную зачастую с экстремальными, а иногда и стрессовыми воздействиями условий соревновательной борьбы на организм спортсмена. Эти условия определяются рангом соревнований, бескомпромиссностью поединка в присутствии многочисленных болельщиков (которые не всегда благожелательно настроены); субъективной оценкой правильности и неправильности действий судей; необходимостью многократного (в процессе одного поединка) развития максимальных фризических и эмоциональных усилий в зависимости от постоянно и быстро изменяющейся ситуации поединка и другими фракторами. Это нередко приводит к эмоциональным нарушениям, которые, вызывая снижение психофизиологической надежности, отрицательно сказываются на результативности технико-тактического мастерства спортсмена. Неудачно выполненное действие в свою очередь (сознательно или бессознательно) вызывает негативно окрашенные эмоциональные реакции разочарования, неуверенности, неудовлетворенности, порождает сомнение в успешности повторения этого действия и усугубляет отрицательное состояние теннисиста, а иногда вызывает стресс [2,3,6].

Напряженный теннисный матч, является не только фризическим состязанием, а представляет еще собой борьбу воли, духа и характеров. И если в начале матча две трети успеха спортсмена зависит от его фризической подготовленности и 
технической оснащённости, то в завершающей стадии - психологический настрой на две трети определяет результат матча.

Естественно, что у некоторых спортсменов еще нет достаточного соревновательного опыта, не все отличаются психической устойчивостью, что, несомненно, отражается на результате. Игрок не всегда может реально оценить свои возможности, силы соперника, соревновательную обстановку, контролировать свои действия, следствием чего является состояние высокой психической напряженности.

Психологическая подготовка теннисистов направлена на формирование у них психической готовности к конкретному соревнованию, то есть на то, чтобы перед соревнованием и в ходе его теннисист находился в психическом состоянии, обеспечивающем эффрективность и надежность саморегуляции поведения и действий $[1,7,8]$.

Цель исследования - определить степень влияния психического состояния на эфффективность соревновательной деятельности теннисистов разной квалификации.

Для достижения поставленной цели были использованы следующие методы исследования: анализ специальной научно-методической литературы, педагогический эксперимент, педагогическое наблюдение, психологическое тестирование, методы математической статистики.

С марта по июнь 2018 года проводился педагогический эксперимент во время Открытого Летнего Первенства Минской области по теннису, среди юношей и девушек до 14 лет по методике Ю.Л. Ханина «Изучение отношения спортсменов к конкретному соревнованию» [4,5].

На основании тренерских заявок на участие в Первенстве за 60 минут до начала соревнований были выбраны 20 теннисистов различной квалификации: 10 игроков с 1 разрядами и 10 игроков в кандидаты мастера спорта. Испытуемые прошли предварительное инструктирование и получили тестовые бланки, где требовалось отвечать на зачитываемые вопросы. Результаты проведенного исследования представлены в таблице 1.

Таблица 1.

Результаты ответов по тестовой методике теннисистов различной спортивной квалификации

\begin{tabular}{|l|c|c|c|c|c|}
\hline \multirow{2}{*}{ Испытуемые } & \multicolumn{4}{|c|}{ Показатели } \\
\cline { 2 - 6 } & Квалификация & $\begin{array}{c}\text { Показатель } \\
\text { уверенности в } \\
\text { себе }\end{array}$ & $\begin{array}{c}\text { Посприятия и } \\
\text { оценки } \\
\text { возможностей } \\
\text { соперников }\end{array}$ & $\begin{array}{c}\text { Показатель } \\
\text { желания } \\
\text { участвовать и } \\
\text { значимость } \\
\text { соревнования }\end{array}$ & $\begin{array}{c}\text { Показатель } \\
\text { зеркальной } \\
\text { самооценки } \\
\text { спортсмена }\end{array}$ \\
\hline 1 & KMC & 1 & 3 & 7 & 0 \\
\hline 2 & KMC & 0 & 4 & 6 & 2 \\
\hline 3 & KMC & 3 & 3 & 7 & 1 \\
\hline 4 & KMC & 2 & 2 & 6 & 3 \\
\hline
\end{tabular}


"Modern Psychology" Scientific Bulletin 2019 , N 2(5)

\begin{tabular}{|c|c|c|c|c|c|}
\hline 6 & KMC & 1 & 3 & 7 & 3 \\
\hline 7 & KMC & 2 & 2 & 5 & 4 \\
\hline 8 & KMC & 3 & 4 & 6 & 2 \\
\hline 9 & KMC & 2 & 3 & 7 & 4 \\
\hline 10 & KMC & 1 & 5 & 6 & 3 \\
\hline \multirow{4}{*}{$\begin{array}{l}\text { Основные } \\
\text { статисти- } \\
\text { ческие } \\
\text { характе- } \\
\text { ристики }\end{array}$} & $\Sigma$ & 15 & 34 & 63 & 24 \\
\hline & $X$ & 1,5 & 3,4 & 6,3 & 2,4 \\
\hline & $\delta$ & 1,54 & 1,87 & 1,23 & 1,57 \\
\hline & Sx & 0,49 & 0,59 & 0,39 & 0,50 \\
\hline 1 & 1 & 6 & 6 & 6 & 7 \\
\hline 2 & 1 & 4 & 7 & 4 & 6 \\
\hline 3 & 1 & 5 & 6 & 7 & 7 \\
\hline 4 & 1 & 3 & 4 & 6 & 7 \\
\hline 5 & 1 & 5 & 5 & 5 & 6 \\
\hline 6 & 1 & 7 & 7 & 7 & 6 \\
\hline 7 & 1 & 5 & 6 & 6 & 6 \\
\hline 8 & 1 & 3 & 7 & 7 & 7 \\
\hline 9 & 1 & 4 & 7 & 7 & 5 \\
\hline 10 & 1 & 3 & 6 & 7 & 6 \\
\hline \multirow{5}{*}{$\begin{array}{l}\text { Основные } \\
\text { статисти- } \\
\text { ческие } \\
\text { характе- } \\
\text { ристики }\end{array}$} & $\Sigma$ & 45 & 61 & 62 & 63 \\
\hline & $\mathrm{Y}$ & 4,5 & 6,1 & 6,2 & 6,3 \\
\hline & $\delta$ & 1,77 & 1,62 & 1,53 & 1,44 \\
\hline & Sx & 0,56 & 0,52 & 0,49 & 0,45 \\
\hline & $\mathrm{P}$ & $<0,05$ & $<0,05$ & $>0,05$ & $<0,05$ \\
\hline
\end{tabular}

Полученные результаты в графической форме представлены на рисунке 1.

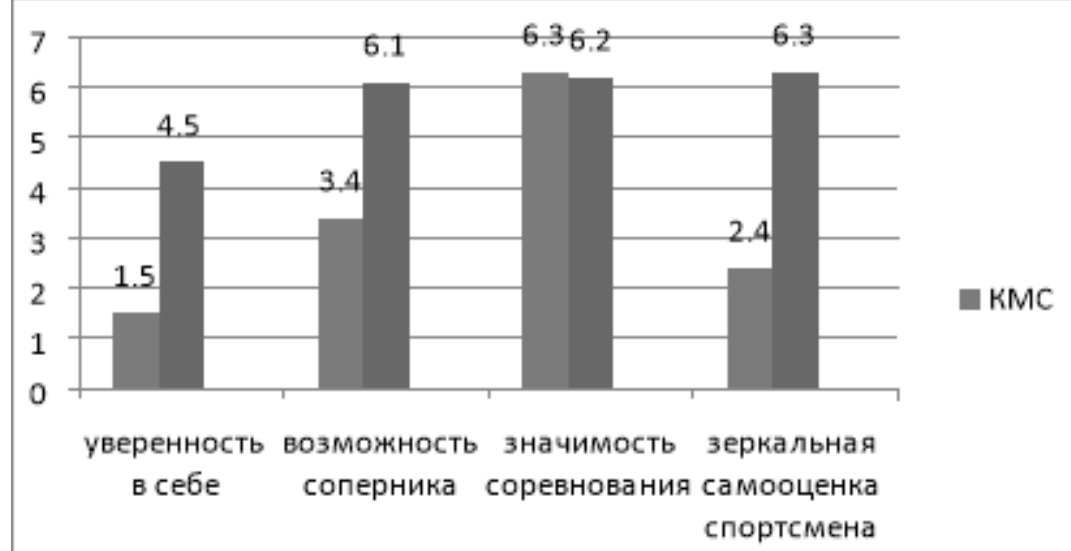

Рисунок 1. - Различия по восприятию теннисистами различной квалификации соревновательной ситуации

На рисунке видно, что у кандидатов в мастера спорта по теннису, по показателю уверенности в себе набрали 1,5 баллов, что говорит о высокой уверенности в своих возможностях. Менее опытные сверстники с результатом 4,5 баллов по группе, уступили в три раза своим товарищам. 
Показатель восприятия и оценки возможностей соперников «смогут ли соперники?» у КМС равен 3,4 баллам. Зная свои возможности, они также хорошо оценивают возможности и более опытных и титулованных соперников. А теннисисты 1 разряда, зная, что слабо технически и тактически подготовлены, оценили возможность соперников в 6,1 балл из 7 баллов возможных.

Показатель желания участвовать и значимость соревнования "хочу ли я?» для КМС равен 6,3 балла, в то же время, как и для теннисистов 1 разряда он также высок - 6,2 балла. Если спортсмен изъявил желание приехать на соревнования, значит, кроме победы он желает повысить свое профессиональное мастерство.

Показатель субъективного восприятия спортсменом оценки его возможностей со стороны других людей «смогу ли я с точки зрения других людей?» у КМС равен 2,4 балла - на их соревновательный результат возлагаются надежды. К теннисистам 1 разряда требования со стороны тренера и товарищей более низки - 6,3 балла по выборке.

В ходе соревнований проводилось педагогическое наблюдение за внешними признаками соревновательного эмоционального состояния каждого из 20 спортсменов (таблица 2).

Таблица 2.

Результаты педагогического наблюдения за внешними признаками соревновательного эмоционального состояния каждого из 20 теннисистов

\begin{tabular}{|c|c|c|c|c|c|}
\hline \multirow{2}{*}{ Испытуемые } & \multirow{2}{*}{ Квалификация } & \multicolumn{4}{|c|}{ Характер эмоциональных проявлений } \\
\hline & & Мимика & Скованность & Тремор & $\begin{array}{l}\text { Вазомоторные } \\
\text { реакции }\end{array}$ \\
\hline 1 & KMC & 4 & 3 & 4 & 4 \\
\hline 2 & KMC & 5 & 5 & 5 & 5 \\
\hline 3 & KMC & 4 & 4 & 3 & 4 \\
\hline 4 & KMC & 5 & 5 & 4 & 5 \\
\hline 5 & KMC & 5 & 4 & 4 & 5 \\
\hline 6 & KMC & 4 & 3 & 4 & 4 \\
\hline 7 & KMC & 5 & 5 & 4 & 5 \\
\hline 8 & KMC & 5 & 4 & 4 & 4 \\
\hline 9 & KMC & 4 & 3 & 4 & 4 \\
\hline 10 & KMC & 3 & 4 & 4 & 3 \\
\hline \multirow{4}{*}{$\begin{array}{l}\text { Основные } \\
\text { статисти- } \\
\text { ческие } \\
\text { характе- } \\
\text { ристики }\end{array}$} & $\Sigma$ & 44 & 40 & 40 & 43 \\
\hline & $\mathrm{X}$ & 4,4 & 4 & 4 & 4,3 \\
\hline & $\delta$ & 1,18 & 1,87 & 0,50 & 1,74 \\
\hline & Sx & 0,37 & 0,59 & 0,47 & 0,55 \\
\hline 1 & 1 & 2 & 3 & 2 & 3 \\
\hline 2 & 1 & 2 & 3 & 3 & 3 \\
\hline 3 & 1 & 3 & 3 & 2 & 3 \\
\hline 4 & 1 & 5 & 4 & 5 & 5 \\
\hline 5 & 1 & 2 & 3 & 2 & 2 \\
\hline 6 & 1 & 4 & 4 & 4 & 5 \\
\hline
\end{tabular}




\begin{tabular}{|l|c|c|c|c|c|}
\hline 7 & 1 & 3 & 3 & 3 & 4 \\
\hline 8 & 1 & 2 & 3 & 2 & 3 \\
\hline 9 & 1 & 3 & 2 & 2 & 3 \\
\hline 10 & 1 & 4 & 4 & 4 & 4 \\
\hline \multirow{2}{*}{$\begin{array}{l}\text { Основные } \\
\text { статисти- }\end{array}$} & $\Sigma$ & 30 чкие \\
\cline { 2 - 6 } $\begin{array}{l}\text { характе- } \\
\text { ристики }\end{array}$ & $\mathrm{Y}$ & 3 & 32 & 29 & 35 \\
\cline { 2 - 6 } & $\delta$ & 1,85 & 3,2 & 2,9 & 3,5 \\
\cline { 2 - 6 } & $\mathrm{Sx}$ & 0,32 & 0,13 & 1,96 & 1,72 \\
\hline
\end{tabular}

Наблюдение показало, что кандидаты в мастера спорта перед соревнованиями спокойны, мимика уверенности, дыхание ровное - 4,4 балла, координированные движения, но с некоторыми заметными усилиями - 4 балла, небольшой тремор пальцев - 4 балла, некоторое покраснение лица - 4,3 балла. Менее опытные спортсмены заметно взволнованы - 3 балла, движения заметно напряженные, некоторая неуклюжесть - 3,2 балла, заметный тремор рук - 2,9 баллов, у большинства игроков покраснение лица или же его бледность - 3,5 баллов.

Таким образом, соревновательные психические состояния кандидатов в мастера спорта с более высоким спортивным стажем оказались благоприятнее, чем у их сверстников, с 1 разрядам, у которых меньше тренировочный и соревновательный стаж.

Результаты проведенного исследования позволяют утверждать, что способность контролировать соревновательные психические состояния развивается по мере спортивного стажа теннисиста в результате многократных соревнований, а также эта способность обуславливает завоевание более высокой спортивной квалификации.

\section{Литература}

1. Акимова, Л.Н. Психология спорта: курс лекций / Л.Н. Акимова. - Одесса: Студия «Негоциант», 2004. - 127 с.

2. Гогунов, Е.Н. Психология физического воспитания и спорта: учеб. пособие для студентов высш. пед. учеб. заведений / Е.Н. Гогунов, Б.И. Мартьянов. - М.: Издательский центр «Академия», 2003. - 288 с.

3. Иванов, В.С. Теннис: учебное пособие / В.С. Иванов, В.В. Коллегорский. М.: ФиС, 2008. - 231 с.

4. Методики психодиагностики в спорте: учеб. пособие для ст-ов пед. ин-тов по спец. 03.03 «Физ. культура» / В.Л. Марищук [и др.]. - 2-е изд., доп. и испр. М.: Просвещение, 1990. - 256 с.

5. Методики психодиагностики в спорте: учеб. пособие для ст-ов пед. ин-тов по спец. 03.03 «Физ. культура» / В.Л. Марищук [и др.]. - 2-е изд., доп. и испр. М.: Просвещение, 1990. - 256 с. 
6. Ормаи, Л. Современный теннис; пер. с венгерского / предисловие Л.С. Макарова. - М.: ФиС, 2005. - 175 с.

7. Ростова, В.А. Большой теннис: учебное пособие / В.А. Ростова, М.О. Ступкина. - Спб.: Высшая административная школа, 2013. - 415 с.

8. Уляев, Л.Г. Психолого-педагогическое сопровождение спортивной деятельности в контексте самореализации личности : монография / Л.Г. Уляев, Е.В. Мельник и др.; под общ. ред. Л.Г. Уляевой. - М.: Издатель Мархотин П.Ю., 2014. - 236 с.

\section{THE STUDY OF MENTAL STATES TENNIS PLAYERS OF VARYING QUALIFICATIONS DURING THE COMPETITION}

Tsagelnikova A. A., Boyarina Yu. S., Tsiganov O. V. (Belarus State University of Physical Culture, Minsk, Belarus)

In this article we examined the mental States tennis players of different skills in the process of competitive activity. Presents the results of psychological testing and the results of pedagogical observation of external signs of competitive tennis before the emotional state of 14 years of various sports skills.

Keywords: mental States, psychological testing, psychological readiness, competitions, emotional manifestations. 